\title{
Article
}

Mycosphere

\section{Molecular characterization and pathogenicity of Diplodia corticola and other Botryosphaeriaceae species associated with canker and dieback of Quercus suber in Algeria}

\section{Smahi $\mathbf{H}^{1}$, Belhoucine-Guezouli $\mathrm{L}^{1}$, Berraf-Tebbal $\mathrm{A}^{2,3}$, Chouih $\mathrm{S}^{2}$, Arkam $\mathbf{M}^{3}$, Franceschini $\mathrm{A}^{4}$, Linaldeddu $\mathrm{BT}^{5}$, Phillips $\mathrm{AJL}^{6}$}

${ }^{1}$ Laboratoire de recherche $N^{\circ} 31$, Département des Ressources Forestières, Faculté des Sciences de la Nature et de la Vie, et des Sciences de la Terre et de l'Univers, Université Abou Bekr Belkaid - Tlemcen, 13000, Tlemcen, Algérie

${ }^{2}$ Département des Biotechnologies, Faculté des Sciences de la Nature et de la Vie, Université Blida 1, 09000, Algérie

${ }^{3}$ Laboratoire de Biologie des Systèmes Microbiens (LBSM), Ecole Nationale Supérieure de Kouba, Algérie

${ }^{4}$ Dipartimento di Agraria, Sezione di Patologia vegetale ed Entomologia, Università degli Studi di Sassari, Viale Italia 39, 07100 Sassari, Italy

${ }^{5}$ Dipartimento Territorio e Sistemi Agro-Forestali, Università di Padova, Viale dell'Università 16, 35020, Legnaro $(P D)$, Italy

${ }^{6}$ Biosystems and Integrative Sciences Institute, Faculty of Science, University of Lisbon, Campo Grande, 1749-016

Lisbon, Portugal

Smahi H, Belhoucine-Guezouli L, Berraf-Tebbal A, Chouih S, Arkam M, Franceschini A, Linaldeddu BT, Phillips AJL 2017 - Molecular characterization and pathogenicity of Diplodia corticola and other Botryosphaeriaceae species associated with canker and dieback of Quercus suber in Algeria. Mycosphere 8(2), 1261-1272, Doi 10.5943/mycosphere/8/2/10

\begin{abstract}
In Algeria cork oak forests are irregularly distributed in the northern regions along the Tell Atlas mountain range. Over the last few decades, severe tree decline and mortality events has been observed in several of the main cork oak forests. Since there is little information about the aetiology of this decline and given the high ecological and economic importance of cork oak ecosystems, a survey was carried out in six forests, M'sila and Hafir (northwestern Algeria), and Ksar Fatma, Haddada, Aïn Zana and Oued El Hout (northeastern Algeria), to establish the fungal pathogens associated with cork oak branch diseases. Isolations from symptomatic branches of 88 declining trees yielded a total of 96 fungal isolates of which 69 belonged to three distinct genera of Botryosphaeriaceae, namely Diplodia, Dothiorella and Lasiodiplodia. On the basis of morphological features and DNA sequence data (ITS and tefl- $\alpha$ ), five species: Diplodia corticola, D. quercivora, D. sapinea, Dothiorella iberica and Lasiodiplodia exigua were identified. The geographical distribution and occurrence of the five species differed greatly among sites. The occurrence of both known lineages of $D$. corticola was also recognised. Pathogenicity trials showed that all the species assayed are pathogenic on cork oak and D. corticola proved to be the most aggressive.
\end{abstract}

Key words - complex aetiology - Diplodia corticola - evolutionary lineages - oak decline 


\section{Introduction}

Cork oak (Quercus suber) is a sclerophyllous evergreen tree species widespread in the Western Mediterranean area through two continent Africa and Europe, where it plays an important ecological and socio-economical role (Marañón 1988, Pinto-Correia 2000). Cork oak ecosystems include a mosaic of habitats spanning from open savannah-like formations to closed sclerophyll forests as a result of the long-term human presence and related activities in the Mediterranean region (Blondel 2006, Bugalho et al. 2011). These heterogeneous forests cover over two million hectares and sustain a rich biodiversity of plants, insects, birds and animals as well as representing an important source of income derived from cork production (Marañón et al. 1999, Campos et al. 2008). In Algeria cork oak forests are irregularly distributed in the northern regions along the Tell Atlas mountain range which cross the country from east to west separating the Mediterranean biome in the north from the Saharan biome to the south (Bussmann 2006). With 410,000 ha Algeria encompass about $18 \%$ of cork oak forests occurring in the Western Mediterranean region (Silva \& Catry 2006).

During the last decades the distribution range of cork oak forests in both European and north African countries has greatly decreased as a result of human-mediated disturbances such as poor or inappropriate management practices, changes in environmental conditions (irregular water regime with prolonged drought periods), fires and attacks by pathogens and pests (Campos et al. 2007, De Sousa et al. 2008, Acácio et al. 2009, Costa et al. 2010, Tiberi et al. 2016). All these adverse factors variable in type, intensity and frequency even at site level, can interact causing a complex disease commonly known as oak decline (Manion 1991). However, recent evidence emphasizes how some invasive pathogens belonging to the genera Diplodia and Phytophthora have had a prominent role in the decline and mortality of cork oak trees in France, Italy, Portugal and Spain (Luque et al. 1989, Brasier 1992, Alves et al. 2004, Moreira \& Martins 2005, Linaldeddu et al. 2017). In particular, the species Diplodia corticola was found to be the most widely distributed and aggressive pathogen involved in the aetiology of cork oak decline (Moricca et al. 2016). This species has not been recorded in Algeria (Phillips et al. 2013, Dissanayake et al. 2016).

Therefore, considering the ecological and economic relevance of cork oak forests in Algeria, the constant expansion of decline phenomena and the absence of information about pathogens involved, a survey was carried out in six Algerian cork oak forests in order to: isolate, identify and characterize the main species involved in the aetiology of cork oak decline with particular emphasis on the Botryosphaeriaceae and investigate the inter- and intraspecific variation in aggressiveness among the main species.

\section{Materials \& Methods}

\section{Sampling, fungal isolation and morphology}

Field surveys were carried out from autumn 2013 to winter 2016 in six cork oak stands, two in north west region of Algeria (Tlemcen National Park and Oran province, respectively) and four in the extreme north-east of the country (El Kala National Park) along the Tell Atlas mountain range (Table 1). Samples of branches showing shoot blight, exudation, sunken canker and dieback symptoms were collected from 88 declining cork oak trees randomly selected (Table 1). All samples were brought to the laboratory and the outer bark surface was cut away with a scalpel. Longitudinal and transversal cuts were made to observe any internal symptoms. Isolations were made from approx. $5 \mathrm{~mm}^{2}$ chips of inner bark and xylem tissues cut aseptically from the margin of symptomatic tissues. All samples were cultured on potato dextrose agar (PDA, Oxoid Ltd.). After incubation at $25^{\circ} \mathrm{C}$ for 1 week, fungal colonies were sub-cultured onto half-strength PDA supplemented with autoclaved holm oak twigs to enhance sporulation. All colonies were kept on the laboratory bench at $20-25{ }^{\circ} \mathrm{C}$ where they received diffused daylight. Colonies with typical Botryosphaeriaceae appearance were initially grouped and identified based on morphological features (e.g. conidial size, shape, colour, striation and septation) according to Phillips et al. (2013). Measurements of morphological structures were made at 400x magnification and recorded using a 
digital camera Leica DFC495 connected to a Leitz Diaplan compound microscope (Leitz, Germany) and Leica Application Suite imaging software v.4.5.0 (Leica Microsystems, Switzerland).

For each fungal species, colony growth characteristics including surface and reverse colony appearance were observed and recorded after 7 days of incubation at $25^{\circ} \mathrm{C}$ in the dark on PDA. For temperature-growth rate studies, agar plugs $(5 \mathrm{~mm}$ diameter) from actively growing cultures of one representative isolate of each species and lineage were placed in the centre of 90-mm Petri dishes containing PDA. Three replicates of each isolate were incubated at 5, 10, 15, 20, 25, 30, 35 and $40^{\circ} \mathrm{C}\left( \pm 0.5^{\circ} \mathrm{C}\right)$ in the dark. Colony diameter of each isolate (mean of two measurements along two lines intersecting at right angles in the centre of the inoculum plug) was measured after 4 days. The experiment was repeated twice. Representative isolates of each species were stored on PDA slants under oil in the culture collection of the Sez. di Patologia vegetale ed Entomologia, Dipartimento di Agraria at the University of Sassari.

Table 1 Cork oak forests surveyed and number of samples collected (one per tree).

\begin{tabular}{|c|c|c|c|c|c|c|c|c|}
\hline \multirow[b]{2}{*}{ Site } & \multirow{2}{*}{$\begin{array}{l}\text { National } \\
\text { Park }\end{array}$} & \multirow[b]{2}{*}{ Forest } & \multirow[b]{2}{*}{ Latitude } & \multirow[b]{2}{*}{ Longitude } & \multirow{2}{*}{$\begin{array}{c}\text { Elevation } \\
\text { (m a.s.l.) }\end{array}$} & \multicolumn{2}{|c|}{ Temperature $\left({ }^{\circ} \mathbf{C}\right)$} & \multirow{2}{*}{$\begin{array}{c}\mathbf{N}^{\mathbf{0}} \\
\text { samples } \\
\text { collected }\end{array}$} \\
\hline & & & & & & $\begin{array}{c}\text { Mean } \\
\max \\
\end{array}$ & $\begin{array}{c}\text { Mean } \\
\text { min }\end{array}$ & \\
\hline 1 & - & M'sila & $35^{\circ} 37^{\prime} 23^{\prime \prime} \mathrm{N}$ & $0^{\circ} 53^{\prime} 00^{\prime \prime} \mathrm{W}$ & 411 & 22.9 & 13.4 & 29 \\
\hline 2 & Tlemcen & Hafir & $34^{\circ} 77^{\prime} 79^{\prime \prime} \mathrm{N}$ & $0^{\circ} 14^{\prime} 29^{\prime \prime} \mathrm{W}$ & 1100 & 20.1 & 9.1 & 28 \\
\hline 3 & El Kala & Ksar Fatma & $36^{\circ} 82^{\prime} 67^{\prime \prime} \mathrm{N}$ & $8^{\circ} 62^{\prime} 75^{\prime \prime} \mathrm{E}$ & 263 & 22.4 & 12.4 & 10 \\
\hline 4 & El Kala & Haddada & $36^{\circ} 88^{\prime} 65^{\prime \prime} \mathrm{N}$ & $8^{\circ} 47^{\prime} 79^{\prime \prime} \mathrm{E}$ & 100 & 23.5 & 13.5 & 8 \\
\hline 5 & El Kala & Aïn Zana & $36^{\circ} 39^{\prime} 76^{\prime \prime} \mathrm{N}$ & $8^{\circ} 19^{\prime} 38^{\prime \prime} \mathrm{E}$ & 180 & 23.0 & 13.0 & 6 \\
\hline 6 & El Kala & Oued El Hout & $36^{\circ} 81^{\prime} 38^{\prime \prime} \mathrm{N}$ & $8^{\circ} 53^{\prime} 05^{\prime \prime} \mathrm{E}$ & 300 & 22.2 & 12.2 & 7 \\
\hline
\end{tabular}

DNA extraction, PCR amplification and sequencing

Sequence analysis was used to confirm identification of all isolates to species level. Instagene Matrix (BioRad Laboratories, Hercules, CA) was used to extract genomic DNA from 5-day-old cultures grown on PDA and incubated at $25{ }^{\circ} \mathrm{C}$. The ITS region was amplified and sequenced with primers ITS1 and ITS4 (White et al. 1990), while the primers EF446f and EF1035r (Inderbitzin et al. 2010) were used to amplify and sequence part of the translation elongation factor 1-alpha gene (tefl- $\alpha$ ). Polymerase chain reaction (PCR) mixtures and amplification conditions were as described by Linaldeddu et al. (2013). The PCR products were purified using the EUROGOLD gel extraction kit (EuroClone S.p.A.) following the manufacturer's instructions. ITS and tefl- $\alpha$ regions were sequenced in both directions by the BMR Genomics DNA sequencing service (www.bmrgenomics.it). Nucleotide sequences were read and edited with FinchTV 1.4.0 (Geospiza, Inc. http://www.geospiza.com/finchtv) and newly generated sequences were deposited in GenBank.

\section{Species identifications}

Isolates were initially grouped according to their colony morphology. Preliminary identifications were based on conidial morphology of cultures grown on $1 / 4$ strength PDA bearing double-autoclaved poplar twigs. Identifications were confirmed by comparing ITS sequences with ex-type and other reference sequences retrieved in BLAST searches of GenBank (Altschul et al. 1990).

Lineages in isolates of $D$. corticola (Linaldeddu et al. 2013) were determined by comparing tef $1-\alpha$ sequences. Sequences, including two isolates of $D$. quercivora in the outgroup, were aligned manually and a maximum parsimony tree was constructed in PAUP with the parameters used by Linaldeddu et al. (2013). The alignment and tree were deposited in Treebase under SN 21656. 


\section{Pathogenicity test}

A total of 20 botryosphaeriaceous isolates including Diplodia corticola (10 isolates), Dothiorella iberica (6 isolate), Diplodia sapinea (2 isolates), Diplodia quercivora (1 isolate), and Lasiodiplodia exigua (1 isolate) were selected for use in pathogenicity trials. Pathogenicity of each selected strain was tested on 3-year-old cork oak seedlings grown in plastic pots $(10 \mathrm{~cm}$ diameter, 1.51 volume). Five seedlings were inoculated with each isolate, and five seedlings were used as control. A shallow wound was made at the stem base of each seedling with a sterile scalpel and inoculated with a 3-4 $\mathrm{mm}^{2}$ mycelial plug taken from the margin of an actively growing culture of each isolate on PDA. A sterile PDA plug was placed on the wound of the control seedlings. The inoculation point was covered with cotton wool soaked in sterile water and wrapped with a piece of aluminium foil secured with Parafilm ${ }^{\circledR}$ to retain moisture. Inoculated seedlings were watered every 3 days and kept in the laboratory for 20 days in daylight and at room temperature ranging between 19 and $24^{\circ} \mathrm{C}$. At the end of the experiment, the length of stem necrotic lesions caused by each isolate was measured after removal of the outer bark.

Re-isolation was attempted by transferring to PDA 10 pieces of inner bark and woody tissues taken around the margin of each lesion. Cultures were grown in daylight and room temperature until fungal colonies developed. Isolates were identified from their micromorphology.

\section{Statistical analyses}

Pathogenicity assay data were checked for normality, then subjected to analysis of variance (ANOVA). Significant differences among mean values were determined using Fisher's least significant differences multiple range test $(P=0.05)$ after one-way ANOVA using XLSTAT software (Addinsoft, Paris, France). Geographic distribution of the two known Diplodia corticola lineages according to their origins in Western Algeria (Tlemcen and Oran) and Eastern Algeria (El Kala) were analyzed by Chi-squared test of a $2 \times 2$ contingency table.

\section{Results}

\section{Field surveys}

Field inspections carried out at six cork oak forests over a three year period showed the widespread presence of declining cork oak trees in two of the main cork oak growing regions of Algeria, Oran and Tlemcen in the west and El-Kala in the east. Declining trees showed a variety of symptoms including twig and shoot blight scattered among healthy foliage with dead leaves still attached, abnormal production of epicormic shoots, a progressive dieback of branches and large sunken cankers with blackish exudates on branches and the trunk. When branch samples with sunken cankers were cross-sectioned, the main internal wood symptoms included characteristic Vshaped necrotic sectors and dark brown rings in the infected sapwood (Fig. 1).

\section{Fungal isolation and identification}

Fungal isolations from 88 samples yielded a total of 96 isolates of which 69 resembled botryosphaeriaceous species based on culture morphology (Table 2). Isolates of other species belonged to the genera Arthrinium (1 isolate), Biscogniauxia (14 isolates), Boeremia (1 isolate), Cryphonectria (5 isolates) and Cytospora (6 isolates).

Based on cultural and morphological features, five groups of botryosphaeriaceous isolates were established. The first group comprised 45 isolates with a white mycelium that gradually turned olivaceous grey to dark grey on PDA (Fig. 1). The mycelial mat was aerial and dense. The cylindrical to ellipsoid with broadly rounded ends conidia were initially hyaline and aseptate. Cultural and morphological features of this group of isolates were consistent with those described for Diplodia corticola by Alves et al. (2004). Identity of isolates was confirmed by analysis of the ITS sequences. BLAST searches in GenBank showed 99-100\% identity with reference sequences of D. corticola including that of the ex-type isolate CBS 112549. Diplodia corticola was the most frequently isolated species, 45 of the 88 cankered branches processed yielded colonies of this 
pathogen. Positive samples were obtained from five of the six cork oak stands surveyed, highlighting the wide distribution and importance of this pathogen in Algerian cork oak stands (Table 2).

Table 2 Number of samples examined from each site and species of Botryosphaeriaceae obtained.

\begin{tabular}{lcccccc}
\hline \multirow{2}{*}{ Site } & No & \multicolumn{5}{c}{ Species } \\
\cline { 3 - 7 } & Samples & $\begin{array}{c}\text { Diplodia } \\
\text { corticola }\end{array}$ & $\begin{array}{c}\text { Diplodia } \\
\text { quercivora }\end{array}$ & $\begin{array}{c}\text { Diplodia } \\
\text { sapinea }\end{array}$ & $\begin{array}{c}\text { Dothiorella } \\
\text { iberica }\end{array}$ & $\begin{array}{c}\text { Lasiodiplodia } \\
\text { exigua }\end{array}$ \\
\hline Hafir (Tlemcen) & 28 & 0 & 0 & 0 & 17 & 1 \\
M'sila (Oran) & 29 & 25 & 1 & 2 & 2 & 1 \\
Ksar Fatma (El-Kala) & 10 & 9 & 0 & 0 & 0 & 0 \\
Haddada (El-Kala) & 8 & 7 & 0 & 0 & 0 & 0 \\
Aïn Zana (El-Kala) & 6 & 2 & 0 & 0 & 0 & 0 \\
Oued El Hout (El-Kala) & 7 & 2 & 0 & 0 & 0 & 0 \\
\hline
\end{tabular}
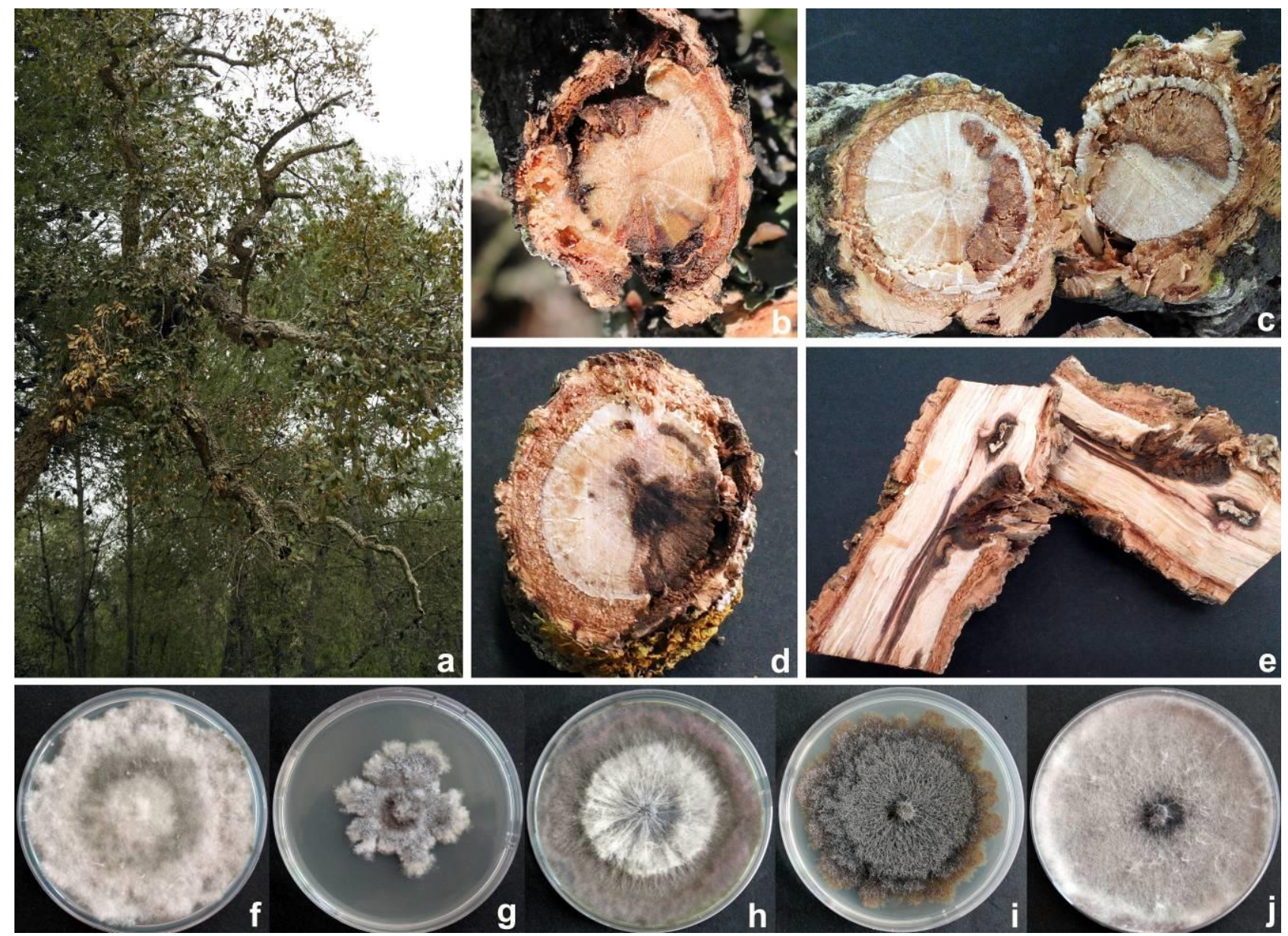

Figure 1 - Cork oak tree with extensive twig and branch dieback (a), main internal symptoms of sectioned branches used for isolations (b-e), colony morphology of Diplodia corticola (f), D. quercivora (g), D. sapinea (h), Dothiorella iberica (i) and Lasiodiplodia exigua (j) after 7 days growth at $25^{\circ} \mathrm{C}$ on PDA in the dark. 


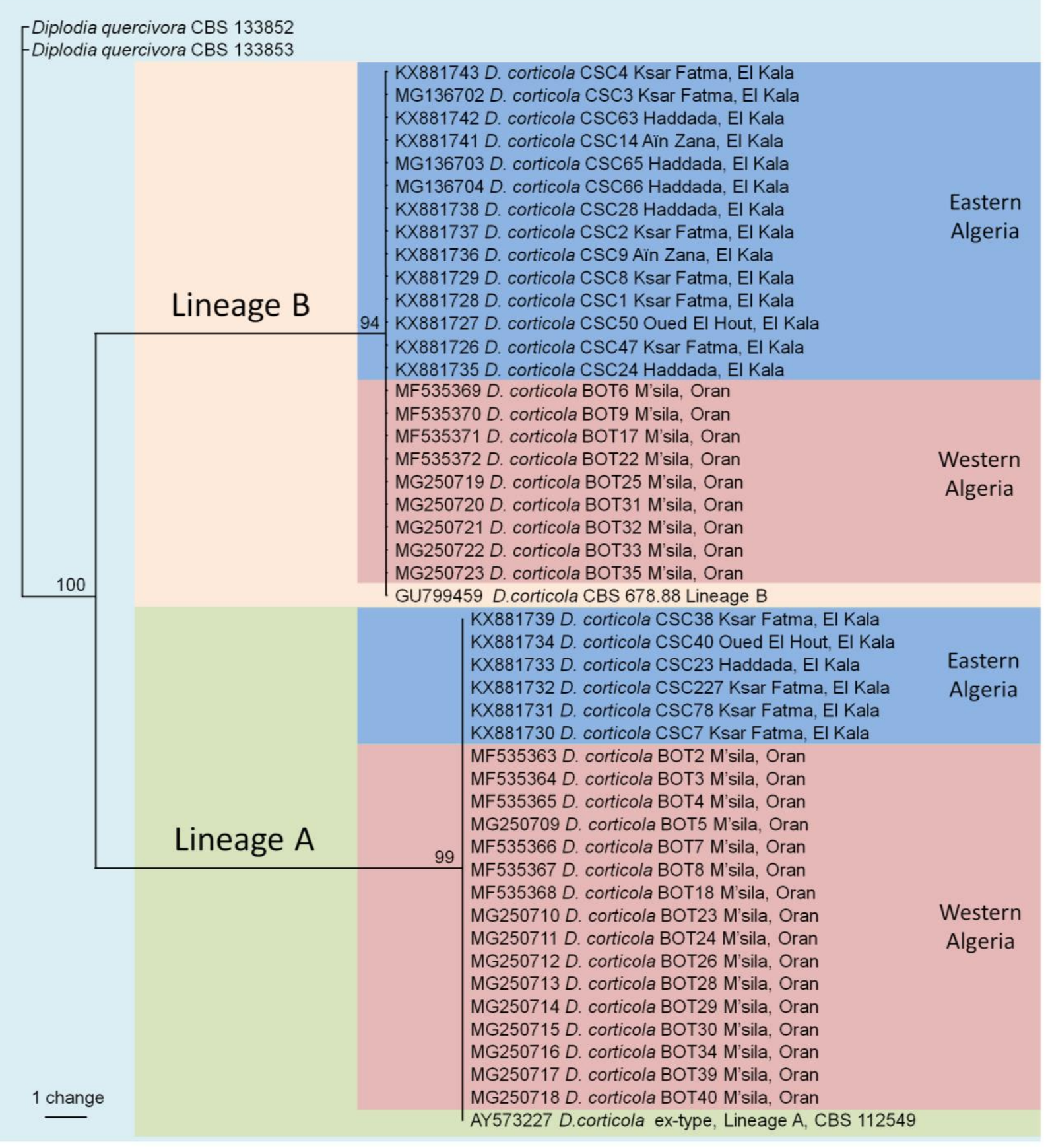

Figure 2 - Single most parsimonious tree resulting from maximum parsimony analysis of tef 1- $\alpha$ sequences of 45 isolates of $D$. corticola from oak trees in two regions in Eastern and Western Algeria. Taxon labels are GenBank accesssion numbers, species, forest and region. The ex-type isolate of $D$. corticola (lineage A from Aveiro, Portugal) and a representative isolate of lineage B of D. corticola (from Girona, Cataluña, Spain) were included. Node values are MP bootstrap values. The tree was rooted to Diplodia quercivora.

Through the analysis of tefl- $\alpha$ sequences, the isolates were grouped according to the two evolutionary lineages known for D. corticola (Linaldeddu et al. 2013). Thus, 22 isolates belonged to lineage A and 23 isolates to lineage B (Fig. 2). Analysis of the geographic distribution of these isolates (Table 3$)$ revealed that lineages and regions were not independent $\left(\chi^{2} 1\right.$ d.f. $=15.46$ $P<0.001)$. Therefore the two lineages are not distributed equally in the two major regions sampled. Lineage A was predominant in Western Algeria and lineage B in Eastern Algeria. 
Table 3 Distribution of lineages A and B of D. corticola according to their origins in Western Algeria (Oran) or Eastern Algeria (El Kala).

\begin{tabular}{l|cc} 
& Lineage A & Lineage B \\
\hline East & 6 & 14 \\
West & 16 & 9 \\
$\chi^{2}=15.46(P<0.001)$ &
\end{tabular}

The second group of isolates was characterized by an appressed and compact mycelium, initially white but becoming dark brown after 3-4 days on PDA (Fig. 1). Conidia from culture were 1-septate thick-walled, brown, ovoid with a broadly rounded apex and truncate base. Based on morphological features, the isolates of this group were identified as Dothiorella iberica (Phillips et al. 2005). The identification was confirmed by analysis of ITS and tefl- $\alpha$ sequences. BLAST analysis showed $100 \%$ identity with the sequences of the Do. iberica isolates available in GenBank including the ex-type culture (CBS 115041). New sequences were deposited in GenBank (Table 5). Isolates of Do. iberica were obtained from symptomatic branches collected in two of the stands surveyed (Table 2). In particular, Do. iberica was the most common species in the site of Hafir located at $1100 \mathrm{~m}$ above sea level and characterized by the lowest mean temperature of all the sites surveyed.

The third group comprised only two isolates. Culture on PDA at $25^{\circ} \mathrm{C}$ developed an aerial, fluffy, grey mycelium with a slight violet pigmentation in the margin of colony (Fig. 1). The oblong to clavate and dark brown conidia produced in culture were typical of Diplodia sapinea (Phillips et al., 2013). The morphological identification was confirmed by sequence analysis of the ITS and tefl- $\alpha$ regions. A BLAST search in GenBank of the sequences obtained in this study revealed an exact match (100\%) with reference sequence of the ex-epitype culture CBS 393.84 of $D$. sapinea. The isolates of $D$. sapinea were obtained from two symptomatic branches collected in the site of M'sila (Table 2).

The fourth group also comprised only two isolates. Cultures on PDA produced a fast-growing aerial mycelium initially white to pale grey, becoming olivaceous-grey on the surface after 3-4 days and dark-brown in the reverse side of the colony (Fig. 1). Conidia were ellipsoid to ovoid, apex and base rounded, thick-walled, initially hyaline and aseptate, becoming one septate and then dark brown with age with longitudinal striations. Colony morphology and the shape and sizes of both paraphyses and conidia were consistent with those described for Lasiodiplodia exigua by Linaldeddu et al. (2015). BLAST analysis of ITS and tefl- $\alpha$ sequence showed $100 \%$ identity with sequences of L. exigua available in GenBank including the ex-type culture (CBS 137785). This species was isolated from cankered branches from Hafir and M'sila in the Tlemcen forest (Table 2).

The fifth group comprised only one isolate from the site of M'sila (Table 2). Colony on PDA grew moderately, with a velvety pale to dark olivaceous mycelium with an irregular and sometime vinaceous margin (Fig. 1). The hyaline, aseptate, smooth, thick-walled, sub-cylindrical to oblongelliptical conidia rarely becoming brown and one septate with age. Both colony and conidia appearance were typical of the species Diplodia quercivora described by Linaldeddu et al. (2013). BLAST searches in GenBank of both ITS and tefl- $\alpha$ sequences showed 100\% identity to reference sequences of representative strains including those of the ex-type culture (CBS 133852).

\section{Cardinal temperatures for growth}

For most species the optimum temperature for growth was $25^{\circ} \mathrm{C}$ with minimum $<5^{\circ} \mathrm{C}$ and maximum between $35-40^{\circ} \mathrm{C}$ (Table 4). The optimum temperature for L. exigua was $25-30^{\circ} \mathrm{C}$ and colonies could grow at $40^{\circ} \mathrm{C}$, while the optimum for $D$. iberica was $20^{\circ} \mathrm{C}$ and maximum between $30-35^{\circ} \mathrm{C}$. Thus, the optimum temperature for growth of $D$. iberica was considerably lower than that recorded for the other species. 
Table 4 Cardinal temperatures $\left({ }^{\circ} \mathrm{C}\right)$ for growth of Botryosphaeriaceae species associated with diseased cork oaks in Algeria.

\begin{tabular}{lccc} 
& Min & Opt & Max \\
\hline D. corticola A & $<5$ & 25 & $35-40$ \\
D. corticola B & $<5$ & 25 & $35-40$ \\
D. quercivora & $<5$ & 25 & $35-40$ \\
D. sapinea & $<5$ & 25 & $35-40$ \\
Do. iberica & $<5$ & 20 & $30-35$ \\
L. exigua & $5-10$ & $25-30$ & $>40$ \\
\hline
\end{tabular}

Table 5 Lesion lengths caused by strains of the five fungal species on cork oak seedlings and numbers of seedlings wilted out of five inoculated. Lesion data are means and standard deviations.

\begin{tabular}{|c|c|c|c|c|c|c|}
\hline \multirow{2}{*}{ Fungal strains } & \multicolumn{3}{|c|}{ Details of strains inoculated } & \multirow{2}{*}{$\begin{array}{l}\text { Mean lesion } \\
\text { length }(\mathbf{c m})^{*}\end{array}$} & \multirow{2}{*}{$\begin{array}{l}\text { Seedling } \\
\text { wilted }\end{array}$} & \multirow{2}{*}{$\begin{array}{l}\text { Re-isolation } \\
\text { Frequency } \\
\text { (\%) }\end{array}$} \\
\hline & ITS & tefl- $\alpha$ & Lineage & & & \\
\hline Diplodia corticola Bot6 & MF535359 & MF535369 & $\mathrm{B}$ & $7.0 \pm 3.1 \mathrm{a}$ & 4 & 100 \\
\hline Diplodia corticola Bot8 & MF535357 & MF535367 & A & $6.2 \pm 2.2 \mathrm{ab}$ & 3 & 100 \\
\hline Diplodia corticola Bot 22 & MF535362 & MF535372 & $\mathrm{B}$ & $6.0 \pm 2.5 \mathrm{a}-\mathrm{c}$ & 2 & 100 \\
\hline Diplodia corticola Bot9 & MF535360 & MF535370 & $\mathrm{B}$ & $6.0 \pm 3.4 \mathrm{a}-\mathrm{c}$ & 3 & 100 \\
\hline Diplodia corticola Bot2 & MF535353 & MF535363 & A & $5.7 \pm 3.8 \mathrm{a}-\mathrm{c}$ & 2 & 100 \\
\hline Diplodia corticola Bot18 & MF535358 & MF535368 & A & $5.2 \pm 2.6 \mathrm{a}-\mathrm{c}$ & 3 & 100 \\
\hline Diplodia corticola Bot4 & MF535355 & MF535365 & A & $4.5 \pm 2.4 \mathrm{a}-\mathrm{d}$ & 3 & 100 \\
\hline Diplodia corticola Bot3 & MF535354 & MF535364 & A & $4.3 \pm 1.2 b-\mathrm{d}$ & 3 & 100 \\
\hline Diplodia corticola Bot17 & MF535361 & MF535371 & B & $3.8 \pm 1.5 \mathrm{~b}-\mathrm{e}$ & 2 & 100 \\
\hline Diplodia corticola Bot7 & MF535356 & MF535366 & A & $3.6 \pm 2.3 \mathrm{c}-\mathrm{f}$ & 1 & 100 \\
\hline Diplodia quercivora Bot19 & MF535381 & MF535391 & - & $4.7 \pm 2.4 \mathrm{a}-\mathrm{c}$ & 1 & 100 \\
\hline Diplodia sapinea Bot1 & MF535379 & MF535389 & - & $1.1 \pm 0.4 \mathrm{~g}$ & 0 & 100 \\
\hline Diplodia sapinea Bot20 & MF535380 & MF535390 & - & $1.0 \pm 0.2 \mathrm{~g}$ & 0 & 100 \\
\hline Dothiorella iberica Bot12 & MF535375 & MF535385 & - & $1.5 \pm 0.2 \mathrm{e}-\mathrm{g}$ & 0 & 100 \\
\hline Dothiorella iberica Bot10 & MF535373 & MF535383 & - & $1.4 \pm 0.5 \mathrm{e}-\mathrm{g}$ & 0 & 100 \\
\hline Dothiorella iberica Bot16 & MF535378 & MF535388 & - & $1.2 \pm 0.2 \mathrm{fg}$ & 0 & 100 \\
\hline Dothiorella iberica Bot15 & MF535377 & MF535387 & - & $1.2 \pm 0.1 \mathrm{fg}$ & 0 & 100 \\
\hline Dothiorella iberica Bot13 & MF535376 & MF535386 & - & $1.0 \pm 0.1 \mathrm{~g}$ & 0 & 100 \\
\hline Dothiorella iberica Bot11 & MF535374 & MF535384 & - & $1.0 \pm 0.4 \mathrm{~g}$ & 0 & 100 \\
\hline Lasiodiplodia exigua Bot 21 & MF535382 & MF535392 & - & $2.1 \pm 1.1 \mathrm{~d}-\mathrm{g}$ & 0 & 100 \\
\hline Control & & & - & 0.0 & 0 & - \\
\hline LSD critical value & & & & 1.99 & & \\
\hline
\end{tabular}

*Values with the same letter do not differ significantly at $P=0.05$ according to Fisher's LSD multiple range test.

\section{Pathogenicity test}

All cork oak seedlings inoculated with $D$. corticola, D. quercivora, D. sapinea, Do. iberica and L. exigua displayed disease symptoms 20 days after inoculation. All fungal strains assayed caused necrotic lesions on the inner bark and vascular tissues that progressed both upwards and downwards from the inoculation points. However, average necrotic lesion lengths (Table 5) differed significantly according to the isolates $\left(F_{19,4}=6.063 ; P<0.001\right)$. Diplodia corticola proved to be the most aggressive species. It caused the most extensive necrotic lesions, which often girdled the stem, causing leaf chlorosis and wilting of the distal portion of the canopy (Table 5). Wilted seedlings reacted by issuing new shoots below the point of inoculation. The average lesion length caused by $D$. corticola differed significantly among the strains, but no significant differences were detected between the two lineages. Diplodia quercivora caused stem and leaf symptoms very 
similar to those of $D$. corticola and no significant differences in average lesion size were detected between these two species.

Strains of D. sapinea, Do. iberica and L. exigua caused significantly smaller necrotic lesions than those caused by the isolates of $D$. corticola and $D$. quercivora. No other visual symptoms were observed in the seedlings inoculated with the strains of these three species (Table 5). No disease symptoms were detected on control seedlings, and the wounds had begun to heal.

All fungal strains were successfully re-isolated from symptomatic tissues (wood and inner bark) of inoculated seedlings, thus fulfilling Koch's postulates.

\section{Discussion}

This study represents the most comprehensive study on the presence, diversity and pathogenicity of Botryosphaeriaceae species associated with declining cork oak trees to date in Algeria. For the first time the direct involvement of Botryosphaeriaceae species in the aetiology of canker and dieback symptoms of cork oak was ascertained in various natural ecosystems in this country. Botryosphaeriaceae species accounted for more than $70 \%$ of the isolates, making this by far the most common taxonomic group associated with branch cankers in declining cork oak trees. In particular, five species belonging to three different genera were isolated and identified by means of morphological characters and DNA sequence data. These species included D. corticola, D. quercivora, D. sapinea, Do. iberica and L. exigua.

Almost all the Botryosphaeriaceae species we identified have previously been detected on cork oak trees (Alves et al. 2004, Phillips et al. 2005, Bragança et al. 2016) with the exception of $D$. sapinea and L. exigua, which are presented here as cork oak pathogens for the first time. This extends the host range of these species and the geographical range of $D$. corticola reported by Dissanayake et al. (2016).

Diplodia corticola was the most frequently isolated fungal species, and our field survey and pathogenicity test data clearly demonstrated that it is the major cause of branch canker and dieback in Algerian cork oak trees. The high frequency with which $D$. corticola was detected in this study agrees with earlier investigations conducted in native oak forests in Europe, North America and Tunisia where this pathogen has been recognised as the main cause of canker and dieback (Linaldeddu et al. 2009, 2017, Dreaden et al. 2011, Lynch et al. 2013, Aćimović et al. 2016, Munch et al. 2017). Linaldeddu et al. (2013) revealed the existence of two distinct evolutionary lineages in D. corticola with a different geographic distribution. In the present study the presence of both lineages was established in Algeria with lineage A dominant in the Western forests and lineage B dominant in the Eastern forests. The different levels of aggressiveness among D. corticola strains was not related to lineages. Existence of intraspecific variability in aggressiveness has recently been reported for D. corticola by Félix et al. (2017) and other Botryosphaeriaceae species such as D. sapinea (de Wet et al. 2002), Diplodia seriata (Elena et al. 2015) and Sardiniella urbana (Linaldeddu et al. 2016a).

Dothiorella iberica was the second most common species isolated in this study. Interestingly, at Hafir it was the dominant species. The sampling site of Hafir is located at $1100 \mathrm{~m}$ elevation and the medium-low temperatures that characterized this site are probably favourable for Do. iberica, which has an optimal temperature for growth lower than other species obtained in this study. In this regard, Do. iberica has recently been recognized as the main pathogen associated with dieback and tree mortality of Monterey cypress (Cupressus macrocarpa) in the district of Bougaâ (north-eastern Algeria) located at $1400 \mathrm{~m}$ elevation (Azouaoui-Idjer et al., 2012). However, in the pathogenicity test Do. iberica proved to be a weak pathogen on cork oak. This finding is consistent with tests conducted on coast live oak (Quercus agrifolia) in California by Lynch et al. (2013), and other woody host such as avocado, English walnut and grapevine (McDonald \& Eskalen 2011, Chen et al. 2014, Carlucci et al. 2015).

The other three species of Botryosphaeriaceae were isolated at low frequency and from only one or two sites. Diplodia sapinea is an important pathogen of conifers worldwide (Phillips et al., 2013), but occasionally it has been reported on angiosperms, although its pathogenicity on this 
taxonomic group of plant was not clearly established (Bettucci et al. 2004, Lazzizera et al. 2008, Zlatković et al. 2016). In the present study D. sapinea was isolated infrequently and from only two samples at M'sila (Oran). In this forest there has been an invasion by Pinus halepensis and the oak trees are surrounded by pine trees. The presence of $D$. sapinea on the $P$. halepensis trees was confirmed and it is likely that the high levels of inoculum contributed to the infections on the cork oak trees. Lasiodiplodia exigua was originally isolated from symptomatic plants of broom bush in Tunisia and pistachio in the U.S.A. (Linaldeddu et al. 2015) and more recently from healthy and diseased baobab trees in different countries in Africa (Benin, Cameroon and Senegal), suggesting a widespread diffusion of this species in the African continent (Cruywagena et al. 2017). In a similar way to $D$. sapinea it is likely that the infections by $L$. exigua could be a result of other hosts in the vegetation surrounding the cork oak forests that could serve as an inoculum source. Diplodia quercivora was first described as causing cankers and dieback on Algerian oak in Tunisia (Linaldeddu et al. 2013) and more recently reported on declining live oak in Florida (Dreaden et al. 2014) and cork oak trees in Portugal (Bragança et al. 2016). The low frequency with which these three species were isolated suggest they play a marginal role in the aetiology of cork oak decline. However, it is interesting to remark that in this study, similarly to other recent works (GonzálezDomínguez et al. 2016, Linaldeddu et al. 2016b, Olmo et al. 2016, Sessa et al. 2016, Cruywagena et al. 2017), a complex and variable community of Botryosphaeriaceae species has been detected from the same host and symptoms.

In conclusion, our data emphasize how fungal species in the Botryosphaeriaceae represent a growing threat to oak forest ecosystems in the Mediterranean climate zone. They also reveal that the diversity of fungal species associated with twig and branch cankers of cork oak trees is greater than previously recognised and this flora may be influenced by environmental conditions and the presence of other hosts.

\section{Acknowledgements}

This work is part of the PhD thesis of H. Smahi. Alan JL Phillips acknowledges the support from Biosystems and Integrative Sciences Institute (BioISI, FCT/UID/ Multi/04046/2013).

\section{References}

Acácio V, Holmgren M, Rego F, Moreira F, Mohren GMJ. 2009 - Are drought and wildfires turning Mediterranean cork oak forests into persistent shrublands? Agroforestry Systems 76, 389-400.

Aćimović SG, Harmon CL, Bec S, Wyka S et al. 2016 - First report of Diplodia corticola causing decline of red oak (Quercus rubra) Trees in Maine. Plant Disease 100, 649.

Alves A, Correia A, Luque J, Phillips AJL. 2004 - Botryosphaeria corticola, sp. nov. on Quercus species, with notes and description of Botryosphaeria stevensii and its anamorph, Diplodia mutila. Mycologia 96, 598-613.

Azouaoui-Idjer G, Della Rocca G, Pecchioli A, Bouznad Z, Danti R. 2012 - First report of Botryosphaeria iberica associated with dieback and tree mortality of monterey cypress (Cupressus macrocarpa) in Algeria. Plant Disease 96, 1073.

Bettucci L, Simento S, Alonso R, Lupo S. 2004 - Endophytic fungi of twigs and leaves of three native species of Myrtaceae in Uruguay. Sydowia 56, 8-23.

Blondel J. 2006 - The "design" of Mediterranean landscapes: a millennial story of humans and ecological systems during the historic period. Human Ecology 34, 713-729.

Bragança H, Neno J, Henriques J, Diogo E, Alves A. 2016 - First report of Diplodia quercivora causing dieback on Quercus suber and in Europe. Plant Disease 100, 2166.

Brasier CM. 1992 - Oak tree mortality in Iberia. Nature 360, 539.

Bugalho MN, Caldeira MC, Pereira JS, Aronson J, Pausas JG. 2011 - Mediterranean cork oak savannas require human use to sustain biodiversity and ecosystem services. Frontiers in Ecology and the Environment 9, 278-286. 
Bussmann RW. 2016 - Vegetation zonation and nomenclature of African Mountains - An overview. Lyonia 11, 41-66.

Campos P, Daly-Hassen H, Ovando-Pol, P. 2007 - Cork oak forest management in Spain and Tunisia: two case studies of conflicts between sustainability and private income. International Forestry Review 9, 610-626.

Campos P, Ovando P, Montero G. 2008 - Does private income support sustainable agroforestry in Spanish dehesa? Land Use Policy 25, 510-522.

Carlucci A, Cibelli F, Lops F, Raimondo ML. 2015 - Characterization of Botryosphaeriaceae species as causal agents of trunk diseases on grapevines. Plant Disease 99, 1678-1688.

Chen S, Morgan DP, Hasey JK, Anderson K, Michailides TJ. 2014 - Phylogeny, morphology, distribution, and pathogenicity of Botryosphaeriaceae and Diaporthaceae from English walnut in California. Plant Disease 98, 636-652.

Cruywagen EM, Slippers B, Roux J, Wingfield MJ. 2017 - Phylogenetic species recognition and hybridisation in Lasiodiplodia: A case study on species from baobabs. Fungal Biology 121, 420-436.

Costa A, Pereira H, Madeira M. 2010 - Analysis of spatial patterns of oak decline in cork oak woodlands in Mediterranean conditions. Annals of Forest Science 67, 204.

de Wet J, Wingfield MJ, Coutinho T, Wingfield BD 2002 - Characterisation of the "C" morphotype of the pine pathogen Sphaeropsis sapinea. Forest Ecology and Management 161, $181-188$.

Dissanayake AJ, Phillips AJL, Li XH, Hyde KD. 2016 - Botryosphaeriaceae: Current status of genera and species. Mycosphere 7, 1001-1073.

Dreaden TJ, Shin K, Smith JA. 2011 - First report of Diplodia corticola causing branch cankers on live oak (Quercus virginiana) in Florida. Plant Disease 95, 1027.

Dreaden TJ, Black AW, Mullerin S, Smith JA. 2014 - First report of Diplodia quercivora causing shoot dieback and branch cankers on live oak (Quercus virginiana) in the USA. Plant Disease $98,282$.

Elena G, Garcia-Figueres F, Reigada S, Luque J. 2015 - Intraspecific variation in Diplodia seriata isolates occurring on grapevines in Spain. Plant Pathology 64, 680-689.

Félix C, Pinto G, Amaral J, Fernandes I et al.. 2017 - Strain-related pathogenicity in Diplodia corticola. Forest Pathology e12366. https://doi.org/10.1111/efp.12366

González-Domínguez E, Alves A, León M, Armengola J. 2016 - Characterization of Botryosphaeriaceae species associated with diseased loquat (Eriobotrya japonica) in Spain. Plant Pathology 66, 77-89.

Inderbitzin P, Bostock RM, Trouillas FP, Michailides TJ. 2010 - A six-locus phylogeny reveals high species diversity in Botryosphaeriaceae from California almond. Mycologia 102, 1350 1368

Lazzizera C, Frisullo S, Alves A, Phillips AJL. 2008 - Morphology, phylogeny and pathogenicity of Botryosphaeria and Neofusicoccum species associated with drupe rot of olives in southern Italy. Plant Pathology 57, 948-956.

Linaldeddu BT, Hasnaoui F, Franceschini A. 2009 - First report of Botryosphaeria corticola affecting Quercus afares and Q. canariensis in Tunisia. Journal of Plant Pathology 91, 234.

Linaldeddu BT, Franceschini A, Alves A, Phillips AJL. 2013 - Diplodia quercivora sp. nov.: a new species of Diplodia found on declining Quercus canariensis trees in Tunisia. Mycologia 105, 1266-1274.

Linaldeddu BT, Deidda A, Scanu B, Franceschini A et al. 2015 - Diversity of Botryosphaeriaceae species associated with grapevine and other woody hosts in Italy, Algeria and Tunisia, with descriptions of Lasiodiplodia exigua and Lasiodiplodia mediterranea sp. nov. Fungal Diversity 71, 201-214.

Linaldeddu BT, Alves A, Phillips AJL. 2016a - Sardiniella urbana gen. et sp. nov., a new member of the Botryosphaeriaceae isolated from declining Celtis australis trees in Sardinian streetscapes. Mycosphere 7, 893-905. 
Linaldeddu BT, Maddau L, Franceschini A, Alves A, Phillips AJL. 2016b - Botryosphaeriaceae species associated with lentisk dieback in Italy and description of Diplodia insularis sp. nov. Mycosphere 7, 962-977.

Linaldeddu BT, Maddau L, Franceschini A 2017 - First report of Diplodia corticola causing canker and dieback of Quercus ilex, Q. petraea and Q. suber in Corsica (France). Plant Disease 101, 256.

Luque J, Girbal J. 1989 - Dieback of cork oak (Quercus suber) in Catalonia (NE Spain) caused by Botryosphaeria stevensii. European Journal of Forest Pathology 19, 7-13.

Lynch SC, Eskalen A, Zambino PJ, Mayorquin JS, Wang DH. 2013 - Identification and pathogenicity of Botryosphaeriaceae species associated with coast live oak (Quercus agrifolia) decline in southern California. Mycologia 105, 125-140.

Manion PD. 1991 - Tree disease concepts. Englewood Cliffs: Prentice Hall.

Marañón T. 1988 - Agro-sylvo-pastoral systems in the Iberian Peninsula: dehesas and montados. Rangelands 10, 255-258.

Marañón T, Ajbilou R, Ojeda F, Arroyo J. 1999 - Biodiversity of woody species in oak woodlands of southern Spain and northern Morocco. Forest Ecology and Management 115, 147-156.

McDonald V, Eskalen A. 2011 - Botryosphaeriaceae species associated with avocado branch cankers in California. Plant Disease 95, 1465-1473.

Moreira AC, Martins JMS. 2005 - Influence of site factors on the impact of Phytophthora cinnamomi in cork oak stands in Portugal. Forest Pathology 35, 145-162.

Moricca S, Linaldeddu BT, Ginetti B, Scanu B et al. 2016 - Endemic and emerging pathogens threatening cork oak trees: management options for conserving a unique forest ecosystem. Plant Disease 100, 2184-2193

Munck IA, Wyka SA, Bohne MJ, Green WJ, Siegert NW. 2017 - First report of Diplodia corticola causing bleeding cankers on black oak (Quercus velutina). Plant Disease 101, 257.

Olmo D, Armengol J, León M, Gramaje D. 2016 - Characterization and pathogenicity of Botryosphaeriaceae species isolated from almond trees on the island of Mallorca (Spain). Plant Disease 100, 2483-2491.

Phillips A, Alves A, Correia A, Luque J 2005 - Two new species of Botryosphaeria with brown, 1septate ascospores and Dothiorella anamorphs. Mycologia 97, 513-529

Phillips AJL, Alves A, Abdollahzadeh J, Slippers B et al. 2013 - The Botryosphaeriaceae: genera and species known from culture. Studies in Mycology 76, 51-167.

Pinto-Correia T. 2000 - Future development in Portuguese rural areas: how to manage agricultural support for landscape conservation? Landscape and Urban Planning 50, 95-106.

Sessa L, Abreo E, Bettucci L, Lupo S. 2016 - Botryosphaeriaceae species associated with wood diseases of stone and pome fruits trees: symptoms and virulence across different hosts in Uruguay. European Journal of Plant Pathology146, 519-530.

Silva JS, Catry F. 2006 - Forest fires in cork oak (Quercus suber L.) stands in Portugal. International Journal of Environmental Studies 63, 235-257.

Tiberi R, Branco M, Bracalini M, Croci F, Panzavolta T. 2016 - Cork oak pests: a review of insect damage and management. Annals of Forest Science 73, 219-232

White TJ, Bruns T, Lee S, Taylor J. 1990 - Amplification and direct sequencing of fungal ribosomal RNA genes for phylogenetics. In: PCR Protocols, a Guide to Methods and Applications (eds. MA Innis, DH Gelfand, JJ Sninsky and J White) Academic Press. San Diego, Ca, USA 315-322.

Zlatković M, Keča N, Wingfield MJ, Jami F, Slippers B. 2017 - New and unexpected host associations for Diplodia sapinea in the Western Balkans. Forest Pathology DOI: 10.1111/efp.12328. 